\title{
NextScour for improving bridge scour design in the United States
}

Haoyin Shan PhD, PE

Research Hydraulic Engineer, Genex Systems/FHWA Turner-Fairbank

Highway Research Center, McLean, VA, USA (Orcid:0000-0002-6358-

5347) (corresponding author: haoyin.shan.ctr@dot.gov)

James Pagenkopf ME

Research Hydraulic Engineer, FHWA Turner-Fairbank Highway Research Center, McLean, VA, USA (Orcid:0000-0001-5392-8628)
Kornel Kerenyi PhD

Research Hydraulic Engineer, FHWA Turner-Fairbank Highway Research Center, McLean, VA, USA

Chao Huang PhD

Research Hydraulic Engineer, Genex Systems/FHWA Turner-Fairbank Highway Research Center, McLean, VA, USA (Orcid:0000-0002-6034-8637)

The US Federal Highway Administration (FHWA) is developing the next-generation scour programme - that is, NextScour - to improve scour analysis for safe and economical bridge foundation design. NextScour recognises that scour phenomena consist of two major components: (a) water and hydraulic forces and (b) erosion resistance of soils and their associated geotechnical effects. Consequently, the programme consists of two focus areas: NextScourHydraulic and NextScour-Geotechnical. NextScour seeks to research and develop a design tool that computes hydraulic loads across the bathymetric domain. When linked to geotechnically derived subsurface erosion maps/ stratigraphy and information of NextScour, the design tool produces instantaneous three-dimensional scour bathymetries around all bridge foundation elements. A bridge replacement project from the Virginia Department of Transportation provided an excellent case study of the potential cost saving by considering NextScour proof-ofconcept results in the design process. The J. Sterling Jones Hydraulics Research Laboratory erosion tests determined the erosion resistance of the clay layer at the bridge foundation, and a hydraulic force depth decay function was developed along with the soil depth. The proof-of-concept analysis showed a potential reduced pier scour estimate by $15.7 \mathrm{feet}(\mathrm{ft})(4.8 \mathrm{~m})$ and contraction scour estimate by $16.4 \mathrm{ft}(5.0 \mathrm{~m}), 44$ and $65 \%$ reductions from the original scour analysis, respectively. NextScour empowers FHWA's future scour analysis with the goal to improve significantly the accuracy of bridge scour estimates.

\section{Notation}

a pier width (feet (ft) or $\mathrm{m}$ )

$D_{50} \quad$ median sediment diameter (ft or m)

e erosion rate (inches/min or $\mathrm{mm} / \mathrm{h}$ )

$\mathrm{Fr}_{1} \quad$ Froude number directly upstream of the pier, $v_{1} /\left(\boldsymbol{g} y_{1}\right)^{1 / 2}$

g acceleration of gravity $\left(\mathrm{ft} / \mathrm{s}^{2}\right.$ or $\mathrm{m} / \mathrm{s}^{2}$ )

$K_{1} \quad$ correction factor for the pier nose shape

$K_{2} \quad$ correction factor for the angle of attack of flow

$K_{3} \quad$ correction factor for the bed condition

$K_{\mathrm{u}} \quad 1.486$ for English units and 1.0 for SI units

$n \quad$ Manning's roughness coefficient

$q_{2 \mathrm{f}} \quad$ unit discharge in the constricted opening $\left(\mathrm{ft}^{2} / \mathrm{s}\right.$ or $\left.\mathrm{m}^{2} / \mathrm{s}\right)$

$v_{1} \quad$ mean flow velocity directly upstream of the pier (ft/s or $\mathrm{m} / \mathrm{s}$ )

$y_{1} \quad$ flow depth directly upstream of the pier (ft or m)

$y_{\mathrm{c}} \quad$ flow depth including clear-water contraction scour (ft or $\mathrm{m}$ )

$y_{\mathrm{s}} \quad$ pier scour depth (ft or $\mathrm{m}$ )

$\gamma \quad$ unit weight of water (pound-force (lbf) $/ \mathrm{ft}^{3}$ or N $/ \mathrm{m}^{3}$ )

$\tau \quad$ shear stress from the flow $\left(\mathrm{lbf} / \mathrm{ft}^{2}\right.$ or $\left.\mathrm{Pa}\right)$

$\tau_{\mathrm{c}} \quad$ critical shear stress for the floodplain material (lbf/ft ${ }^{2}$ or $\mathrm{Pa}$ )

\section{Introduction}

The Federal Highway Administration (FHWA) Scour Program (the programme) came into existence because of the 1987 scour-induced failure of the I-90 Schoharie Creek Bridge and the resulting findings by the National Transportation Safety Board (NTSB, 1987) that called for greater FHWA oversight. Subsequent scour-related bridge failures at US 51 Hatchie River (1989) and I-5 Arroyo Pasajero Creek (1995) further emphasised the programme need and scope. However, in response to these types of bridge failures and in an effort to respond quickly with the programme guidance to owners, the objectives were largely reactive in nature. For example, the initial scour-potential assessments were generally focused on the use of existing hydraulic methods. These approaches were incrementally advanced over time but with little recognition of the potential geotechnical resistance or other engineering considerations that influence scour prediction. To illustrate, current practice relies on empirical and simplified one-dimensional (1D) design equations in Hydraulic Engineering Circular Number 18 (HEC-18, Arneson et al., 2012) for predicting scour for individual foundation components by assuming a uniform layer of soil characterised using $D_{50}$. This potentially results in a conservative scour design.

The I-35W Bridge failure in 2007 (although not scour related) led to a new emphasis on applying risk-based, data-driven approaches to all aspects of the FHWA bridge programme, including scour (Krolak and Henderson, 2016). As a result, FHWA instituted a combined hydraulics and geotechnical scour programme that has a common vision to implement successfully a next-generation scour programme (NextScour) through programmatic direction, research, technical guidance and deployment. The goal is to improve scour design and to provide safe, economical and innovative bridge foundation design. 
The NextScour programme aligns with the US Department of Transportation's and FHWA's safety, infrastructure, innovation, and accountability strategic goals.

Aligning with NextScour, the Collaborative Hydraulics: Advancing to the Next Generation of Engineering initiatives in the FHWA's Every Day Counts Rounds 4 and 5 encourage designers to use advanced two-dimensional (2D) flow hydraulics to compute flow data for improved scour prediction. However, the HEC-18 scour equations are 1D, and in some cases, the advantages of 2D flow data are lost. HEC-18 equations also have substantial limitations when addressing the soil erosion resistance of subsurface layers.

NextScour recognises that the phenomenon of scour consists of two major aspects or components, $(a)$ consideration of water and hydraulic forces (loads) and (b) the erosion resistance of soils and their associated geotechnical effects (resistance). NextScour institutes a new direction that refocuses and aligns those geotechnical and hydraulic components within a true multidisciplinary framework with outcomes that provide more certainty and reduced project costs.

\section{Next-generation scour design}

In its initial phase, which lasted over 8 years, NextScour research developed the In-situ Scour Testing Device (ISTD) to understand and address soil erosion resistance better. Concurrently, NextScour also focused on using computational fluid dynamics (CFD) to understand and predict hydraulic forces more accurately. More recently, geotechnical research within NextScour sought to understand the erosion resistance contributions of soil types, strengths, depths and variability. Planned research includes erosion testing (ET) using field and lab erosion tests, erosion indexing (EI) to correlate erosion with geotechnical properties and erosion map (EM) development that will retain ET and EI data and link these to subsurface stratigraphy. This preliminary geotechnical research of erosion resistance is already showing promising insights.

For the next phase, NextScour seeks to research and develop a design tool that computes hydraulic loads across the bathymetric domain. When linked to geotechnically derived subsurface EMs/ stratigraphy and information of NextScour, the design tool produces instantaneous three-dimensional (3D) scour bathymetries around all bridge foundation elements (Figure 1). The General Thomas Highway (Route (Rte.) 671) Bridge scour study discussed later in this paper demonstrated the effectiveness of the NextScour approach for actual projects.

Looking ahead, it will take many years to develop fully and introduce a 3D scour tool into regular practice (Figure 2). Onedimensional scour uses current HEC-18 equations and typically 1D hydraulic modelling. Two-dimensional scour uses HEC-18 equations combined with 2D hydraulic modelling. Current research is focused on 3D scour, which integrates 2D hydraulics and an automated CFD scour tool with an embedded soil erosion function.

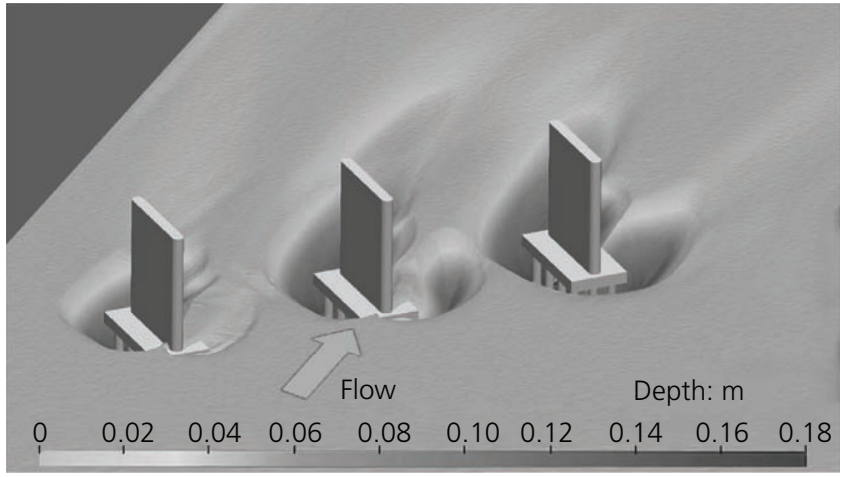

Figure 1. Three-dimensional scour bathymetry for triple complex piers

Anticipated modelling preference

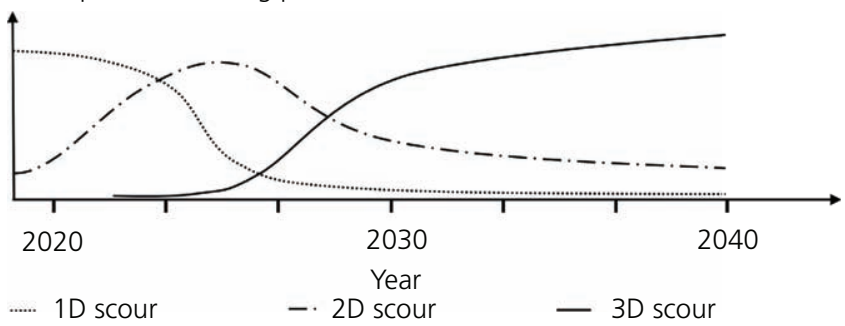

Figure 2. Hydraulic trends and goals of NextScour

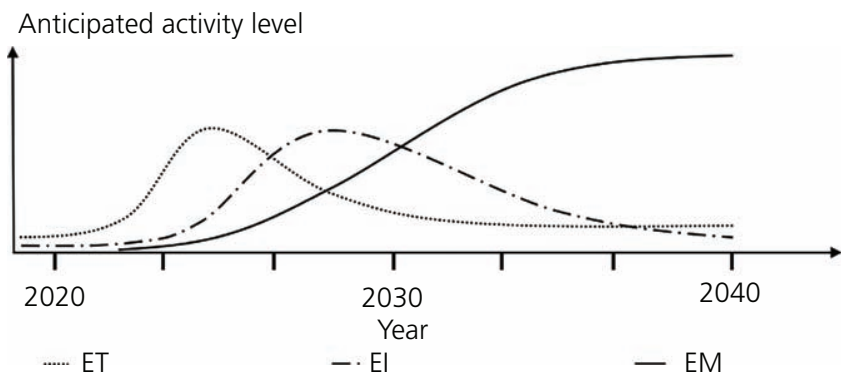

Figure 3. Geotechnical trends and goals of NextScour

EMs (Figure 3) are expected to follow similar trends, requiring many years to develop fully and be introduced into the NextScour programme towards improving scour predictions. ET includes laboratory and field ET. EI intends to express erosion data in terms of soil geotechnical and geophysical properties. The development of EMs in the long run will include subsurface erosion stratigraphy with geographic-information-system-referenced coordinates.

\section{Erosion analysis}

\subsection{Erosion tests}

Since 2011, FHWA has developed the Ex-situ Scour Testing Device (ESTD), ISTD and Portable Scour Testing Device (PSTD) to conduct 
physical ET of various soils. The fully automated ESTD measures the erodibility of soil in a Shelby tube under well-controlled flow conditions. The testing system integrates an industrial robot, an underwater laser scanner, two filter cylinders, a hydraulic piston and a direct shear sensor (Shan et al., 2021a), as shown in Figure 4. During an erosion test, the ESTD maintains a soil surface that is flush with the channel bed at all times. The robotic arm precisely moves the underwater laser scanner over the soil to determine if the soil level needs to be adjusted. The scanner continuously maps the soil surface and calculates the difference between the average soil surface and the ESTD channel bed at a certain frequency. A non-zero value signals the programme-controlled hydraulic piston to extrude soil out of the Shelby tube. The direct shear sensor measures the bed shear stress on the soil. Information pertaining to flow rate, shear stress, soil surface elevation and piston positions are recorded. The slope of the linear function that fits the data of the piston positions represents the soil erosion rate. With recorded shear stresses and erosion rates, the critical shear stress of the soil can be extrapolated. An automated data-processing program has also been developed to process the data quickly. The ESTD enables quick, precise and costeffective laboratory erosion tests. Test procedures were outlined by Shan et al. (2015).

The ISTD is a patented device developed by the FHWA (Shan et al., 2018). It is composed of an innovative erosion head, sensors, pumps and pipes that enable water flow to erode soil in situ. In a field erosion test, the erosion head and connected pipes are lowered into a standard geotechnical steel casing that resides inside a hollow-stem auger. Both the casing and auger are driven into the ground by a conventional geotechnical drill rig. Water circulated through the ISTD produces a high-speed horizontal radial flow between the erosion head and the exposed soil surface below, resulting in erosion. As soil is eroded, the erosion head is continuously lowered to maintain a constant gap between the head and the soil surface. The speed at which the erosion head descends represents the soil erosion rate. The flow rate is converted into shear stress using a calibration equation between the ISTD and the ESTD that is developed in the laboratory. In a standard ISTD field test, multiple pairs of erosion rate and flow rate data points are

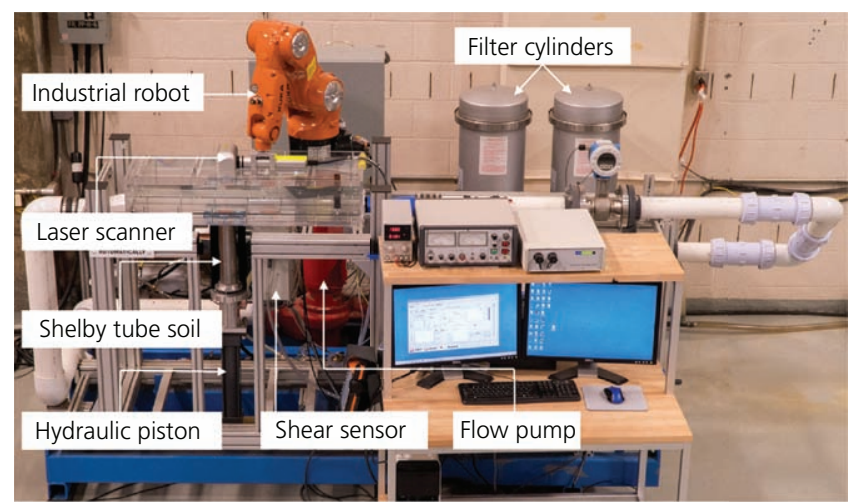

Figure 4. Layout of the ESTD collected (where the flow rate is then converted into shear stress). The critical shear stress is then determined by extrapolating a power curve to fit through these data pairs to find the point where the erosion rate is zero. Shan et al. (2018) explained the details of the ISTD components and the operational procedure of an ISTD erosion test. Figure 5 shows the field set-up of the ISTD together with a conventional drill rig and water pump. FHWA has demonstrated the ISTD in 18 states across the USA since June 2018 (Shan et al., 2021b) as shown in Figure 6.

The PSTD is a simplified version of the ISTD. The erosion mechanism and data collection in both devices are identical. The set up of the PSTD in the field is shown in Figure 7. Instead of eroding soils at the original depth, the PSTD tests soils in Shelby tubes that are sampled and brought above ground. Therefore, it increases the efficiency of fieldwork by separating erosion tests from the geotechnical drilling operations. Although the erosion test is no longer performed in the borehole, the soil sample experiences much fewer disturbances before testing because soil transportation and storage are avoided compared with typical laboratory testing.

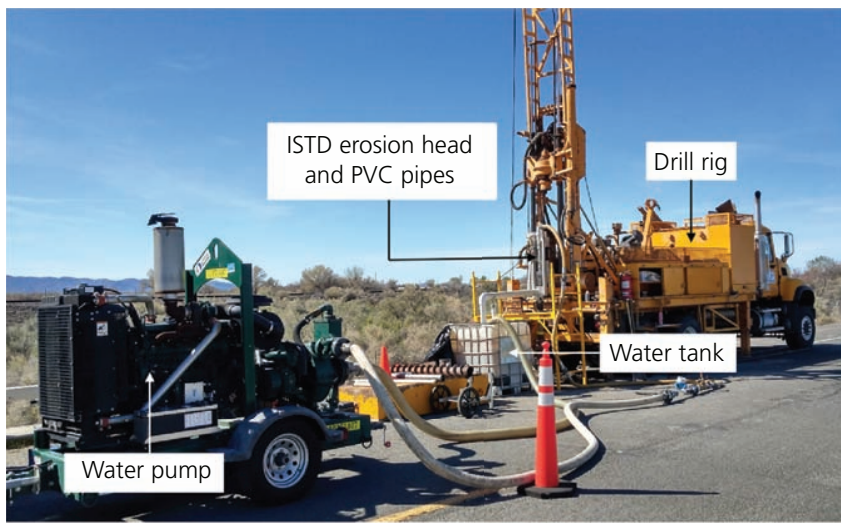

Figure 5. Field set-up of the ISTD. PVC, poly(vinyl chloride)

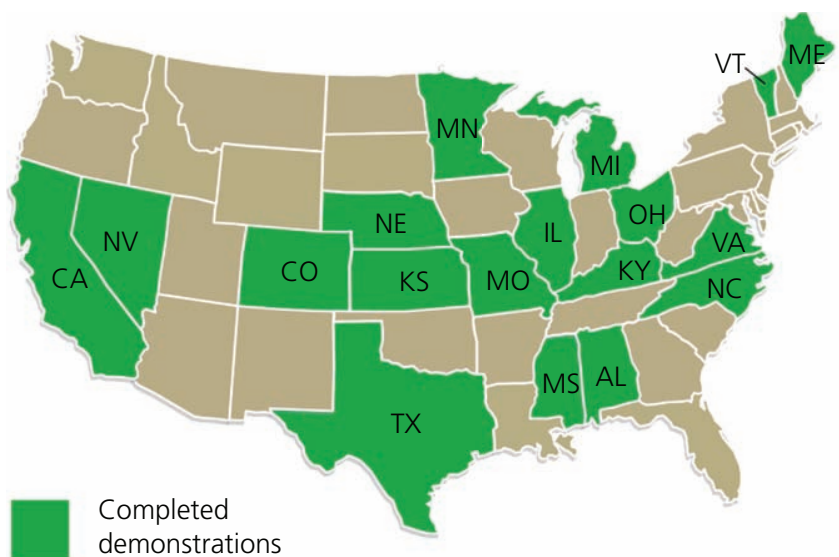

Figure 6. Eighteen ISTD demonstrations across the USA 


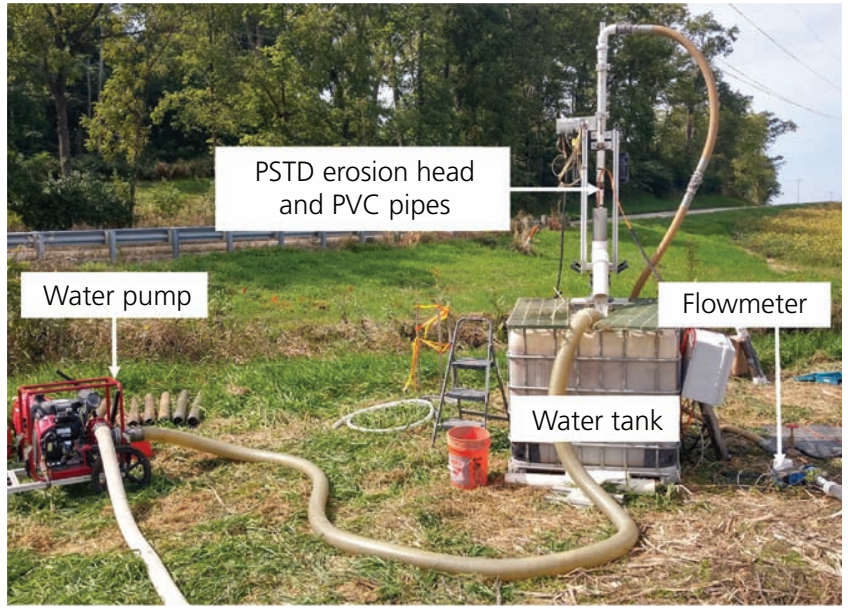

Figure 7. Field set-up of the PSTD. PVC, poly(vinyl chloride)

Another benefit of the PSTD system is that Shelby tube samples can be visibly inspected before testing to find out if the Shelby tube was damaged during the push, and no time is wasted attempting an erosion test underground in a crumpled tube, which could happen in an ISTD erosion test if hard clay or obstructionlike gravel is encountered. Additionally, the PSTD greatly simplifies the overall package by eliminating the steel casing and poly(vinyl chloride) pipes of the ISTD, which are bulky to transport and time-consuming to assemble. Finally, since the PSTD erosion test is performed at the ground level, the power requirements of the water pump are reduced and a smaller, portable pump is utilised instead of renting and mobilising a larger pump from a commercial vendor.

\subsection{Erosion indexing}

FHWA has conducted a preliminary study of correlating soil erosion parameters with geotechnical index properties such as unconfined compressive strength, water content, plasticity index and percentage of fine material. Shan et al. (2015) proposed equations for calculating the critical shear stress and erosion rate of a fine-grained soil based on the index properties of the soil and the eroding shear stress from the flow. These equations serve as preliminary EI functions because they were developed based on a limited database from one particular type of clay.

\section{NextScour case study}

\subsection{Project background}

The Rte. 671 Bridge over the Nottoway River and the Overflow Bridge near Franklin, VA, are located about 186 miles $(300 \mathrm{~km})$ south of Washington, DC. Both five-span bridges were built in 1960 and are owned by the Virginia Department of Transportation (VDOT). Recent routine inspections identified both bridges as structurally deficient and in need of replacement. The newly proposed bridges have three spans and are similar in length to the existing bridges. A consultant for VDOT completed the flood frequency analysis and 1D Hydrologic Engineering Center's River
Analysis System (HEC-RAS) flow simulation in the basin. They calculated a contraction scour depth of 25.4 feet $(\mathrm{ft})(7.7 \mathrm{~m})$ and local scour depths at both new piers to be around $35.5 \mathrm{ft}(10.8 \mathrm{~m})$ for the 100-year flood event. The abutment scour depth was about $51 \mathrm{ft}(15.5 \mathrm{~m})$. Since the geotechnical exploration indicated that an approximately $10 \mathrm{ft}$ thick $(3 \mathrm{~m})$ clay layer exists at a depth of $10 \mathrm{ft}$ $(3 \mathrm{~m})$ below the riverbed, VDOT sent Shelby tube samples to FHWA to determine the erosion resistance of the clay layer. VDOT also performed the cone penetration test at the site for soil characterisation. A 2D hydraulic simulation and a hydraulic force depth decay were combined with the erosion resistance of the clay layer to conduct the scour analysis for the Rte. 671 Bridge replacement project.

\subsection{Hydraulic simulation}

FHWA performed the flow simulation for the 100-year flood event using the Sedimentation and River Hydraulics-2D (SRH2D) model. The model included a total river length of 3.8 miles $(6 \mathrm{~km}), 2.7$ miles $(4.3 \mathrm{~km})$ upstream and 1.1 miles $(1.7 \mathrm{~km})$ downstream of the Rte. 671 Bridge. The 2D model used the 100year flow rate, $45800 \mathrm{ft}^{3} / \mathrm{s}\left(1297 \mathrm{~m}^{3} / \mathrm{s}\right)$, at the upstream (inlet) boundary and a rating curve at the downstream (outlet) boundary. Since a measured rating curve was not available, the substitute rating curve was obtained by inserting the upstream and downstream cross-sections of the 2D model into the 1D HECRAS model and obtaining the water surface elevations at the $2 \mathrm{D}$ downstream cross-section under different flow rates.

The water surface elevation at the cross-section of the 2D downstream boundary agrees well with the results of the HECRAS model. At the cross-section of the $2 \mathrm{D}$ upstream boundary, the water surface elevation is $1 \mathrm{ft}(0.3 \mathrm{~m})$ lower than that in the HEC-RAS model. Figure 8 shows the flow depth and velocity vectors in the $2 \mathrm{D}$ model. The 100 -year flood is conveyed through both bridges. The Rte. 671 Bridge conveys a flow rate of

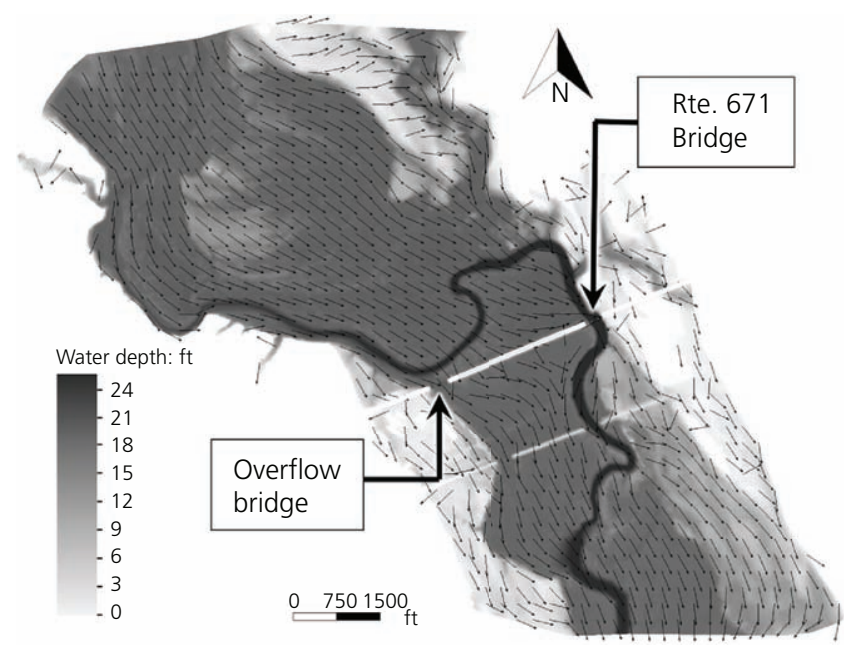

Figure 8. SRH-2D flow depth and velocity vectors for the 100-year flood event. $1 \mathrm{ft}=0.305 \mathrm{~m}$ 
$27000 \mathrm{ft}^{3} / \mathrm{s} \quad\left(765 \mathrm{~m}^{3} / \mathrm{s}\right)$, which is close to the flow rate of $28279 \mathrm{ft}^{3} / \mathrm{s}\left(801 \mathrm{~m}^{3} / \mathrm{s}\right)$ calculated by the HEC-RAS model. The overflow bridge conveys a flow rate of $15800 \mathrm{ft}^{3} / \mathrm{s}\left(447 \mathrm{~m}^{3} / \mathrm{s}\right)$, and the remaining $3000 \mathrm{ft}^{3} / \mathrm{s}\left(85 \mathrm{~m}^{3} / \mathrm{s}\right)$ flow partially inundates the road between the two bridges.

Figure 9 plots the flow simulation cross-sectional results $100 \mathrm{ft}$ $(30 \mathrm{~m})$ upstream of the bridges. Both bridges are elevated relative to their approaches; therefore, only the approaches were overtopped and the bridges experience partial pressure flow. The inundation of the roadway starts at about $650 \mathrm{ft}(198 \mathrm{~m})$ west of the right abutment of the Rte. 671 Bridge until $200 \mathrm{ft}(61 \mathrm{~m})$ east of the left abutment of the overflow bridge.

Figure 10 plots the cross-sectional flow parameters $100 \mathrm{ft}(30 \mathrm{~m})$ upstream of the Rte. 671 Bridge in a much smaller area, showing the bridge details including two piers and the lower chord of the bridge. The flow velocity dropped from $4.5 \mathrm{ft} / \mathrm{s}(1.4 \mathrm{~m} / \mathrm{s})$ to $1.5 \mathrm{ft} / \mathrm{s}$

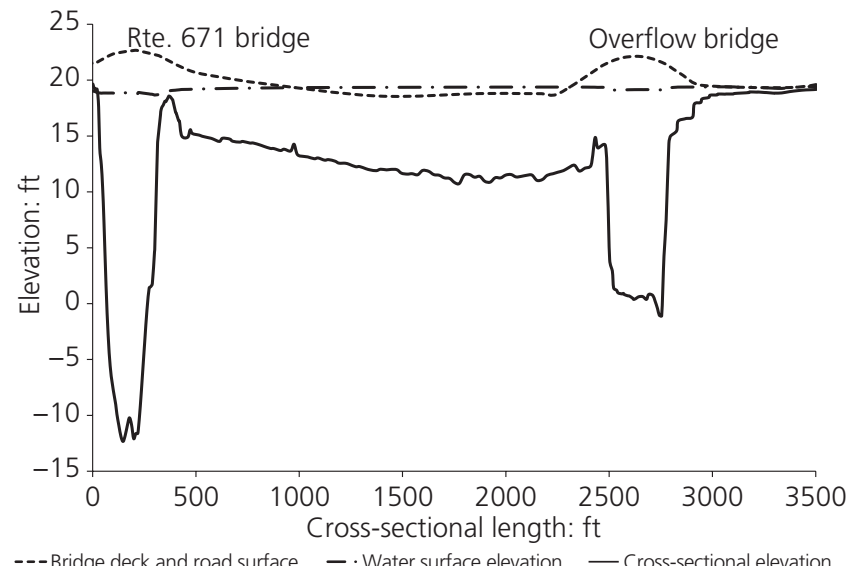

Figure 9. Water surface elevation $100 \mathrm{ft}(30 \mathrm{~m})$ upstream of both bridges. $1 \mathrm{ft}=0.305 \mathrm{~m}$

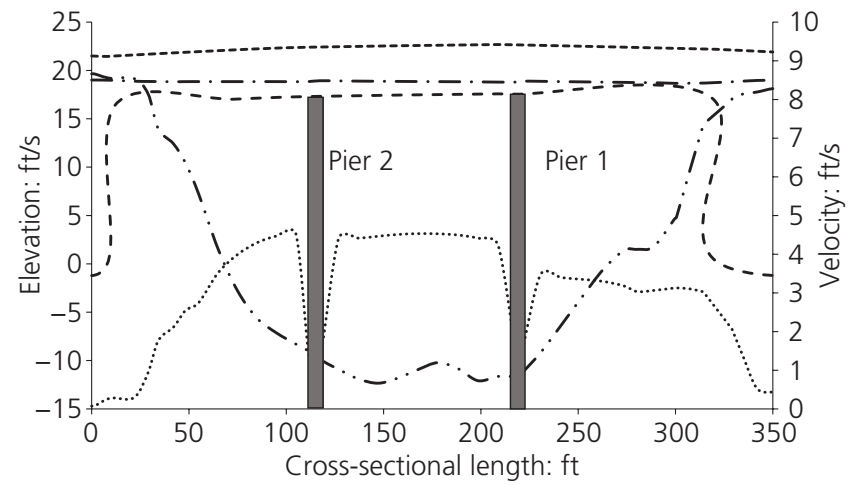

--- Bridge deck surface _- Water surface elevation

- - Bridge low chord - - C Cross-sectional elevation

.... Velocity

Figure 10. Flow parameters $100 \mathrm{ft}(30 \mathrm{~m})$ upstream of the Rte. 671 Bridge. $1 \mathrm{ft}=0.305 \mathrm{~m}$
$(0.46 \mathrm{~m} / \mathrm{s})$ in front of both piers. The cross-section $100 \mathrm{ft}(30 \mathrm{~m})$ upstream of the bridge piers is selected as the approaching crosssection for scour calculation. Flow parameters are listed in Table 1.

\subsection{Comparison of scour analysis}

\subsubsection{Current design practice}

VDOT's consultant utilised a 1D HEC-RAS model to obtain the flow parameters for the 100-year flood event and HEC-18 scour equations to compute the scour depth. The computed contraction, pier and abutment scour depths were $25.4 \mathrm{ft}(7.7 \mathrm{~m}), 35.5 \mathrm{ft}$ $(10.8 \mathrm{~m})$ and $51 \mathrm{ft}(15.5 \mathrm{~m})$, respectively. Based on the scour observation of a 50-year flood in 1999, VDOT suspected that these scour calculations were unrealistically conservative.

\subsubsection{NextScour erosion tests and water load depth decay} 4.3.2.1 ISTD EROSION TESTS

FHWA conducted an ISTD field test close to pier 3 of the Rte. 671 Bridge in March 2019. The ISTD erosion test was done on a barge upstream of the bridge. Previous geotechnical borings revealed soil strata (Figure 11) containing $9 \mathrm{ft}(2.7 \mathrm{~m})$ of fine sand $\left(D_{50}\right.$ of $0.12 \mathrm{~mm})$, followed by $10 \mathrm{ft}(3.0 \mathrm{~m})$ of fat clay, $5 \mathrm{ft}(1.5 \mathrm{~m})$ of fine sand and $15 \mathrm{ft}(4.6 \mathrm{~m})$ of coarser sand $\left(D_{50}\right.$ of $\left.0.42 \mathrm{~mm}\right)$.

The targeted ISTD erosion test depth was from 10.3 to $11.8 \mathrm{ft}$ (3.1 to $3.6 \mathrm{~m})$. The measured erosion rates and corresponding shear stress from the flows are plotted in Figure 12. An erosion function in the form of $e=a \times\left(\tau-\tau_{\mathrm{c}}\right)^{b}$ was fitted through these data points using the least-squares method. The coefficient of determination, $R^{2}$, indicates that the quality of the fit is good when its value is close to 1. The fitting gives the critical shear stress and coefficients $a$ and $b$. The critical shear stress of the clay layer was extrapolated to be 0.09 pound-force $(\mathrm{lbf}) / \mathrm{ft}^{2}(4.2 \mathrm{~Pa})$ with an $R^{2}$ of 0.8 . The erosion function was defined by the equation

1. $e=0.03 \times(\tau-0.09)^{1.6}$

where $\tau$ is in units of pounds-force/square foot and $e$ is in units of inches/minute.

\subsubsection{ESTD EROSION TESTS}

During the ISTD demonstration, Shelby tube samples were collected near the test location, and laboratory erosion tests using the ESTD were conducted for clays from 9.0 to $9.3 \mathrm{ft}$ ( 2.7 to $2.8 \mathrm{~m})$ and 11.5 to $12 \mathrm{ft}(3.5$ to $3.7 \mathrm{~m})$ below the riverbed.

Table 1. Approaching flow parameters from the SRH-2D model

\begin{tabular}{|lccccc|} 
Location & $\begin{array}{c}\text { Flow } \\
\text { depth: } \\
\mathbf{f t}\end{array}$ & $\begin{array}{c}\text { Flow } \\
\text { rate: } \\
\mathbf{f t}^{3} / \mathbf{s}\end{array}$ & $\begin{array}{c}\text { Velocity: } \\
\mathbf{f t} / \mathbf{s}\end{array}$ & $\begin{array}{c}\text { Contracted } \\
\text { width: } \mathbf{f t}\end{array}$ & $\begin{array}{c}\text { Angle } \\
\text { of } \\
\text { attack: }\end{array}$ \\
\hline Main channel & 29.8 & 27000 & - & 298 & - \\
Pier 1 & 29.8 & - & 5.0 & - & 19.4 \\
Pier 2 & 29.8 & - & 5.0 & - & 16.2 \\
\hline
\end{tabular}

$1 \mathrm{ft}=0.305 \mathrm{~m} ; 1 \mathrm{ft}^{3}=0.0283 \mathrm{~m}^{3}$ 


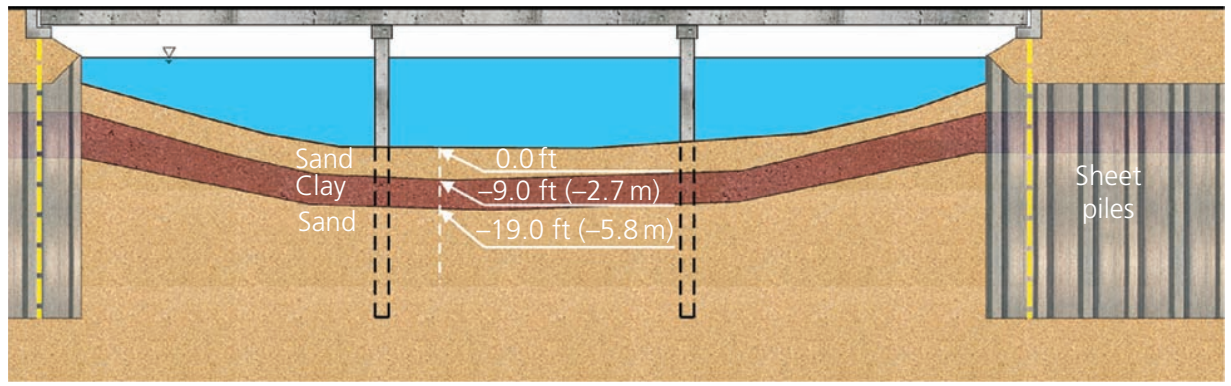

Figure 11. Approximate soil strata at the foundation of the Rte. 671 Bridge

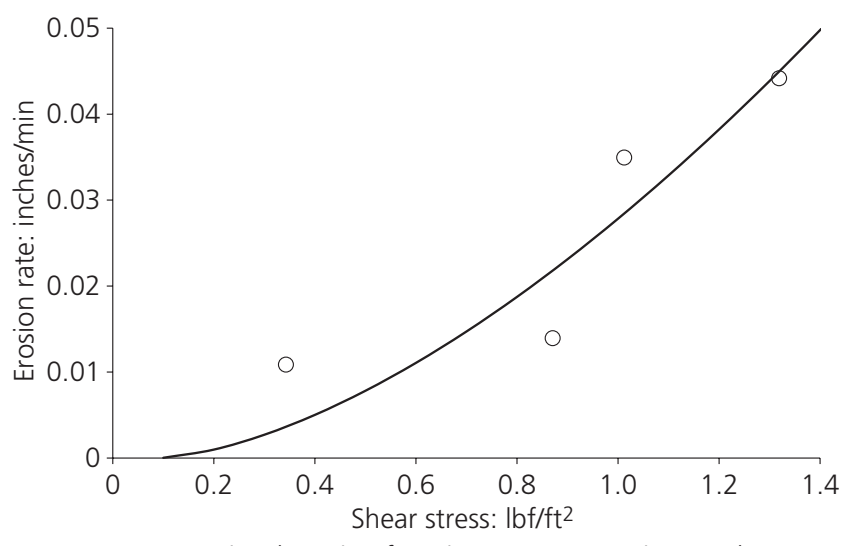

-Fitted erosion function oISTD erosion results

Figure 12. ISTD erosion test results for clay from 10.3 to $11.8 \mathrm{ft}$ (3.1 to $3.6 \mathrm{~m}$ ). 1 inch $=25.4 \mathrm{~mm} ; 1 \mathrm{lbf} / \mathrm{ft}^{2}=47.9 \mathrm{~Pa}$

Further evaluation of the Shelby tube samples indicated that the clay changed from fat clay to lean clay with trace to little fine sand at the interface of $11.5 \mathrm{ft}(3.5 \mathrm{~m})$. Therefore, it was assumed that the $10 \mathrm{ft}(3 \mathrm{~m})$ clay could be separated into two uniform layers: a top clay layer from 9.0 to $11.5 \mathrm{ft}(2.7$ to $3.5 \mathrm{~m})$ and a bottom clay layer from 11.5 to $19.0 \mathrm{ft}$ (3.5 to $5.8 \mathrm{~m}$ ).

The ESTD testing protocol is followed.

- The typical duration of an erosion test for one flow rate/ velocity setting is $10 \mathrm{~min}$.

- Shear stresses are recorded separately from erosion tests.

- The erosion surface laser scan controls the piston advancement and is fully automated.

- The erosion rate is computed by correlating laser scan surfaces of eroded soil surfaces within time increments.

- With the recorded shear stresses and erosion rates, a critical shear of soil samples can be extrapolated.

The measured erosion rates and corresponding shear stress from the flows are plotted in Figures 13 and 14. Similar to the data fit of ISTD erosion results, the critical shear stresses of both clay layers were extrapolated to be $0.4 \mathrm{lbf} / \mathrm{ft}^{2}(19.2 \mathrm{~Pa})$ and $0.12 \mathrm{lbf} / \mathrm{ft}^{2}(5.7 \mathrm{~Pa})$

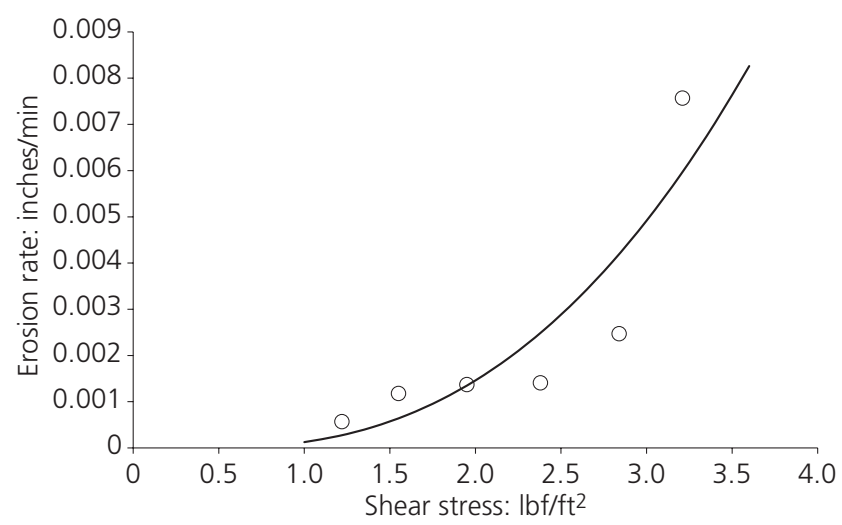

- Fitted erosion function o ESTD erosion results

Figure 13. ESTD erosion test results for clay from 9.0 to $11.5 \mathrm{ft}$ (2.7 to $3.5 \mathrm{~m}$ ). 1 inch $=25.4 \mathrm{~mm} ; 1 \mathrm{lbf} / \mathrm{ft}^{2}=47.9 \mathrm{~Pa}$

with $R^{2}$ values of 0.79 and 0.72 , respectively. The erosion functions for both layers were defined by Equations 2 and 3, respectively.

2. $e=0.00045 \times(\tau-0.4)^{2.5}$

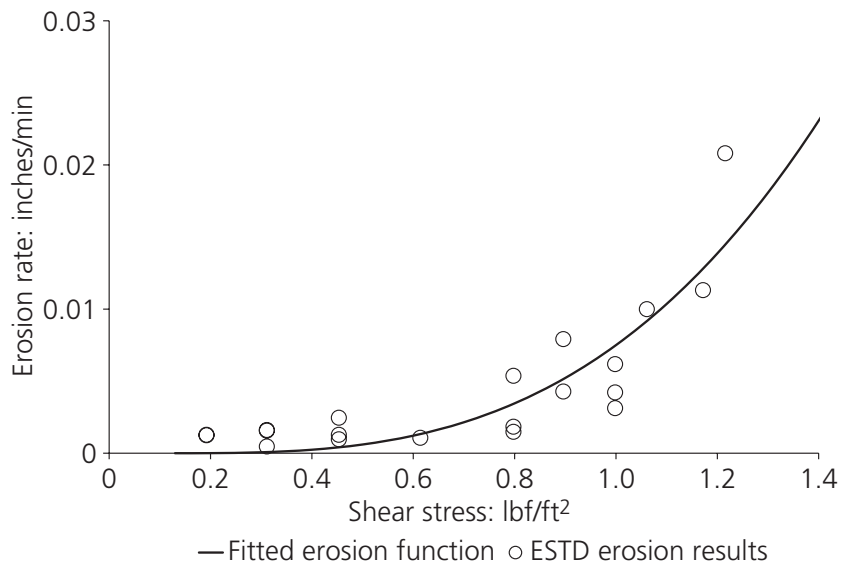

Figure 14. ESTD erosion test results for clay from 11.5 to $19.0 \mathrm{ft}$ (3.5 to $5.8 \mathrm{~m}$ ). 1 inch $=25.4 \mathrm{~mm} ; 1 \mathrm{lbf} / \mathrm{ft}^{2}=47.9 \mathrm{~Pa}$ 
3. $e=0.011 \times(\tau-0.12)^{3}$

where $\tau$ is in units of pounds-force/square foot and $e$ is in units of inches/minute.

Since the ISTD test stopped at $11.8 \mathrm{ft}(3.6 \mathrm{~m})$, the critical shear stress was assumed for the entire clay layer to a depth of $19 \mathrm{ft}$ $(5.8 \mathrm{~m})$. Comparison between Equations 1 and 3 reveals that critical shear stresses from both ISTD and ESTD tests are close (0.09 against $0.12 \mathrm{lbf} / \mathrm{ft}^{2}(4.2$ against $5.7 \mathrm{~Pa})$ ) for the bottom clay layer from 10.3 to $19.0 \mathrm{ft}$ ( 3.1 to $5.8 \mathrm{~m})$ and 11.5 to $19.0 \mathrm{ft}$ (3.5 to $5.8 \mathrm{~m})$. The difference in the starting depth of the bottom clay layer could be related to the spatial variation of soils because the locations of the ISTD test hole and ESTD soil sampling hole were several feet apart from each other.

\subsubsection{WATER LOAD DEPTH DECAY}

As the scour hole develops, the hydraulic eroding force decreases - and this process is called water load depth decay. Equation 8.7 from HEC-18 (Equation 4) calculates the clear-water contraction scour depth.

4. $y_{\mathrm{c}}=\left(\frac{\gamma}{\tau_{\mathrm{c}}}\right)^{3 / 7}\left(\frac{n q_{2 \mathrm{f}}}{K_{\mathrm{u}}}\right)^{6 / 7}$

where $y_{\mathrm{c}}$ is the flow depth including clear-water contraction scour; $n$ is Manning's roughness coefficient; $q_{2 \mathrm{f}}$ is the unit discharge in the constricted opening accounting for non-uniform flow distribution; $\tau_{\mathrm{c}}$ is the critical shear stress of the floodplain material; $\gamma$ is the unit weight of water; and $K_{\mathrm{u}}$ is 1.486 for English units and 1.0 for SI units.

Equation 4 can be rearranged into the decay function (Equation 5), a correlation between the shear stress and the contraction scour depth.

5. $\tau_{\mathrm{c}}=\frac{m^{2} q_{2 \mathrm{f}}^{2}}{K_{\mathrm{u}}^{2} y_{\mathrm{c}}^{7 / 3}}$

However, such a correlation cannot be applied herein since the 100 -year flood partially inundated both bridges. The orifice flow theory can be utilised to calculate the downstream flow depth before the contraction scour occurs. When the downstream flow depth is known, various contracted flow depths can be obtained by assuming a number of contraction scour depths. Then, the shear stress from the flow at each assumed contracted flow depth can be calculated using Equation 5 .

With a flow rate of $27000 \mathrm{ft}^{3} / \mathrm{s}\left(765 \mathrm{~m}^{3} / \mathrm{s}\right)$ through the Rte. 671 Bridge and a Manning's $n$ value of 0.05 , the calculated initial flatbed shear stress is $0.21 \mathrm{lbf} / \mathrm{ft}^{2}(10 \mathrm{~Pa})$ for the case of only new piers considered $(298 \mathrm{ft}(90.9 \mathrm{~m})$ of bridge opening). Since the four pile caps of existing bridge piers may remain, the pile cap width was assumed to be $5 \mathrm{ft}(1.5 \mathrm{~m})$. The contracted bridge opening decreases to $278 \mathrm{ft}(84.8 \mathrm{~m})$ with all new piers and existing pile caps considered. Therefore, the initial flatbed shear stress increases to $0.24 \mathrm{lbf} / \mathrm{ft}^{2}(11.5 \mathrm{~Pa})$. Figure 15 shows the shear decay as the scour hole deepens. At a depth of $9 \mathrm{ft}(2.7 \mathrm{~m})$, the shear stress from flow decreases to 0.11 and $0.13 \mathrm{lbf} / \mathrm{ft}^{2}$ (5.3 and 6.2 Pa) for both cases, less than the critical shear stress of the top clay layer. This indicates that the clay layer would stop the contraction scour at a depth of $9 \mathrm{ft}(2.7 \mathrm{~m})$.

The abutment scour is further calculated by applying an amplification factor of 1.3 to the contraction scour depth. The abutment scour depth is calculated to be $20.6 \mathrm{ft}(6.3 \mathrm{~m})$. The pier scour is calculated using Equation 7.1 of HEC-18 (Equation 6).

6. $\frac{y_{\mathrm{s}}}{a}=2.0 K_{1} K_{2} K_{3}\left(\frac{y_{1}}{a}\right)^{2} \mathrm{Fr}_{1}^{0.43}$

where $y_{\mathrm{s}}$ is the pier scour depth; $a$ is the pier width; $K_{1}, K_{2}$ and $K_{3}$ are the correction factors for the pier nose shape, angle of attack of flow and bed condition, respectively, and are determined from HEC-18; $y_{1}$ is the flow depth directly upstream of the pier; and $\mathrm{Fr}_{1}$ is the Froude number directly upstream of the pier, $v_{1} /\left(\boldsymbol{g} y_{1}\right)^{1 / 2}$, where $\boldsymbol{g}$ is the acceleration of gravity $\left(\mathrm{ft} / \mathrm{s}^{2}\right.$ or $\mathrm{m} / \mathrm{s}^{2}$ ) and $v_{1}$ is the mean flow velocity directly upstream of the pier.

Together with the rule of thumb of HEC-18 where the maximum pier scour is limited to 2.4 times the pier width, the maximum pier scour depth is determined to be $10.8 \mathrm{ft}(3.3 \mathrm{~m})$. The scour depths near the Rte. 671 Bridge are summarised in Table 2. The upstream basin consists of mainly forested and agricultural lands, and the Nottoway River appears to be stable and no long-term channel scour is assumed.

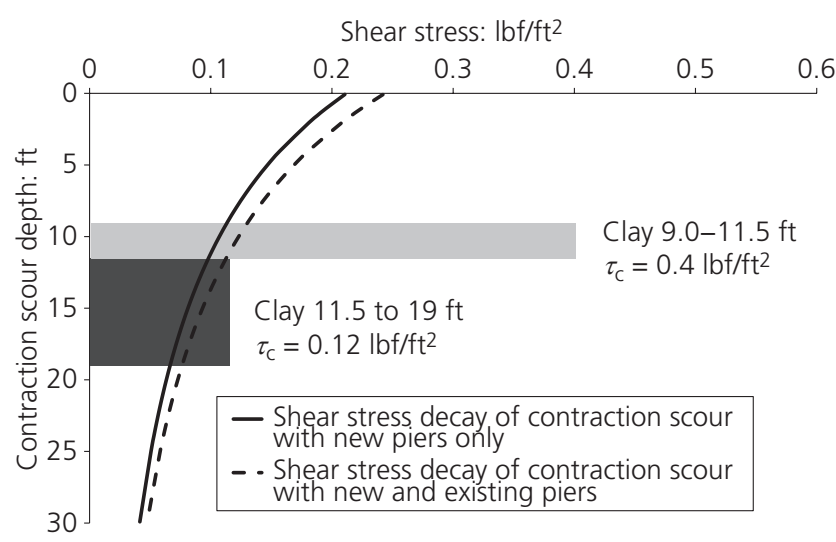

Figure 15. Shear stress decay of contraction scour using SRH-2D results. $1 \mathrm{ft}=0.305 \mathrm{~m} ; 1 \mathrm{lbf} / \mathrm{ft}^{2}=47.9 \mathrm{~Pa}$ 
Table 2. Scour calculations using SRH-2D flow parameters

\begin{tabular}{lcccccc} 
Location & $\begin{array}{c}\text { Contraction: } \\
\mathrm{ft}\end{array}$ & \multicolumn{2}{c}{ Local scour: ft } & $\begin{array}{c}\text { Long- } \\
\text { term } \\
\text { scour: } \mathrm{ft}\end{array}$ & $\begin{array}{c}\text { Total } \\
\text { scour: } \\
\mathrm{ft}\end{array}$ \\
Main channel & 9.0 & - & - & 0.0 & 9.0 \\
Pier 1 & 9.0 & 10.8 & - & 0.0 & 19.8 \\
Pier 2 & 9.0 & 10.8 & - & 0.0 & 19.8 \\
Abutments & - & - & 20.6 & 0.0 & 20.6
\end{tabular}

$1 \mathrm{ft}=0.305 \mathrm{~m}$

\subsubsection{Preliminary NextScour CFD design tool}

A preliminary NextScour CFD design tool was developed using the OpenFoam software program and a scour model written in Python. The OpenFoam software program simulated the flow condition near the bridge, and the scour model calculated the scour bathymetry at a given time. The time step for flow simulation varied from 1 to $10 \mathrm{~ms}$, while the scour model ranged from 1 to $30 \mathrm{~min}$. First, the original riverbed information was imported into the OpenFoam software program as a solid boundary. After one time step of flow calculation, shear stress on the riverbed was extracted and exported to the scour model, where the bed surface was deformed to reflect changing scour depths using the erosion functions for different soil layers (Equations 1-3). The maximum scour depth for one cell in the bed surface was limited to $10 \mathrm{~mm}$ per time step. The OpenFoam software program then resumed the flow simulation with the updated river bathymetry. This iteration between the OpenFoam software program and the scour model continued until the shear stress in the scour hole equalled the critical shear stress of the soil - that is, at the condition where no further erosion happened.

The first $9 \mathrm{ft}(2.7 \mathrm{~m})$ of soil had a $D_{50}$ of $0.12 \mathrm{~mm}$. Its critical shear stress was $0.0015 \mathrm{lbf} / \mathrm{ft}^{2}(0.07 \mathrm{~Pa})$. The flow simulation revealed the initial bed shear stress was $0.21 \mathrm{lbf} / \mathrm{ft}^{2}(10 \mathrm{~Pa})$, so it was reasonable to assume that the $9 \mathrm{ft}(2.7 \mathrm{~m})$ sand would be quickly washed away. The bed shear stress after that decreased to $0.16 \mathrm{lbf} / \mathrm{ft}^{2}$ (6 Pa), which was smaller than the critical shear stress of the top clay layer from 9.0 to $11.5 \mathrm{ft}$ ( 2.7 to $3.5 \mathrm{~m})$. That means no erosion would happen in that clay layer. So contraction scour should stop at $9 \mathrm{ft}(2.7 \mathrm{~m})$, confirming the calculation in Section 4.3.2. The pier scour was calculated by using HEC-18 equations with the flow parameter of the $2 \mathrm{D}$ simulation. Scour analysis in both Sections 4.3.2 and 4.3.3 reduced the contraction scour estimate by $16.4 \mathrm{ft}(5.0 \mathrm{~m})$ and the pier scour estimate by $15.7 \mathrm{ft}$ $(4.8 \mathrm{~m})$, which equalled reductions of 65 and $44 \%$, respectively, from the original scour analysis.

\section{Conclusions}

The current HEC-18 scour calculation mainly focuses on the flow characteristics and neglects the geotechnical properties of multilayered soils at the bridge foundations. Often, the flow parameters are obtained from 1D simulations, which can be improved by more informative 2D simulations. FHWA is developing NextScour to improve the accuracy of scour analysis for a safer and more economical bridge foundation design by separating the scour phenomenon into two components: hydraulic and geotechnical. The NextScour hydraulic programme advances the understanding of the shear stress decay as the scour depth increases, while the NextScour geotechnical programme determines the erosion function and critical shear stress of soils. By comparing the shear stress from the flow (load) and the critical shear stress of soil (resistance), engineers can quickly determine at what depth scour should reach equilibrium.

The Rte. 671 Bridge replacement project from VDOT provided an excellent case study for cost savings by considering NextScour proof-of-concept results in the design process. Two methods of using NextScour were detailed in this VDOT case study. The first method determined the erosion resistance of the clay layer at the bridge foundation by field and laboratory erosion tests and coupled that with the hydraulic force decay along with the soil depth. The second method used the automated CFD scour design tool that coupled the OpenFoam software program and a scour model written in Python. By updating the shear stress calculation with the updated riverbed geometry and considering scour depth calculation using the calculated shear stress and soil erosion function, the final scour depth was calculated. Both methods similarly indicated reduction in the contraction and pier scour estimates by 65 and $44 \%$ from the original scour analysis. The advantage of the CFD scour is that the model can be easily modified, changing either the soil layer properties, including strength or thickness, or the flow characteristics, including depth and velocity, in order to test easily a wide range of cases to calculate the resulting scour depths to assist in foundation design.

Recommendations for further work involving NextScour include (a) more case studies using NextScour for practical projects across the USA to demonstrate the actual cost saving and (b) further development of the automated CFD scour model for more robust and accurate scour analysis.

\section{REFERENCES}

Arneson L, Zevenbergen L, Lagasse P and Clopper P (2012) Evaluating Scour at Bridges, 5 th edn. Federal Highway Administration Washington, DC, USA. HEC-18, FHWA-HIF-12-003.

Krolak J and Henderson D (2016) Implementing a successful risk-based, data-driven scour program. Journal of the Transportation Research Board 2588(1): 163-171, https://doi.org/10. 3141/2588-18

NTSB (National Transportation Safety Board) (1987) Highway Accident Report-Collapse of New York Thruway (I-90) Bridge over the Schoharie Creek, near Amsterdam, New York, April 5, 1987. NTSB, Washington, DC, USA. NTSB/HAR-88/02.

Shan H, Shen J, Kilgore R and Kerenyi K (2015) Scour in Cohesive Soils. Federal Highway Administration, Washington, DC, USA. FHWA-HRT15-033.

Shan H, Wiblishauser O, Kerenyi K et al. (2018) An in situ scour testing device for determining soil erosion resistance. In Scour and Erosion IX: Proceedings of the 9th International Conference on Scour and Erosion (ICSE 2018), November 5-8, Taipei, Taiwan (Keh-Chia Y (ed.)). CRC Press/Balkema, Leiden, the Netherlands, pp. 559-566. 
Shan H, Wiblishauser O, Kerenyi K, Uhrig M and Huang C (2021a) Efficient automated laboratory testing of erosion resistance for finegrained soils. Proceedings of the 10th International Conference on Scour and Erosion, Arlington, VA, USA. paper no. 147.
Shan H, Pastrich D, Pagenkopf J et al. (2021b) In-situ scour testing device demonstrations at 18 State Departments of Transportation. Proceedings of the 10th International Conference on Scour and Erosion Arlington, VA, USA. paper no. 148.

\section{How can you contribute?}

To discuss this paper, please email up to 500 words to the editor at journals@ice.org.uk. Your contribution will be forwarded to the author(s) for a reply and, if considered appropriate by the editorial board, it will be published as discussion in a future issue of the journal.

Proceedings journals rely entirely on contributions from the civil engineering profession (and allied disciplines). Information about how to submit your paper online is available at www.icevirtuallibrary.com/page/authors, where you will also find detailed author guidelines. 